\title{
An empirical investigation on the effects of asymmetric information and growth opportunities on dividend polices: A case study of private Iranian banks
}

\author{
Fariba Moslehi*
}

Faculty Member, Department of Accounting, School of Management and Human Sciences, Tehran North Branch, Islamic Azad University (IAU), Tehran, Iran

\begin{tabular}{l}
\hline C H R O N I C L E \\
\hline Article history: \\
Received October 14, 2012 \\
Received in revised format \\
24 December 2012 \\
Accepted 5 January 2013 \\
Available online \\
January 182013 \\
\hline Keywords: \\
Asymmetric information \\
Growth opportunity \\
Dividend policy \\
Tehran Stock Exchange
\end{tabular}
\begin{abstract}
A B S T R A C T
Dividend plays an important role on changing profitability in any business units including banking industry. In this paper, we present an empirical survey to study the effect of asymmetric information and growth opportunities on dividend policies among some private banks in Iran. The proposed study of this paper gathers the necessary information from all private banks whose shares are listed in Tehran Stock Exchange over the period 2005-2011. The study uses regression analysis to study the effects of various factors where dividend distribution policy is considered as a function of four independent variables namely spread, bank size, growth opportunity and cash flow. The results of the survey indicate that there are some positive and meaningful relationships between growth opportunity and dividend pay (0.003308), between bank size and dividend pay (0.019497) and between bank size and dividend pay $(0.168821)$.
\end{abstract}

(C) 2013 Growing Science Ltd. All rights reserved.

\section{Introduction}

Dividend plays an important role on changing profitability in any business units including banking industry. A high dividend may increase some investors' interest in keeping shares of companies for long term especially in Tehran Stock Exchange. However, a high ratio of dividend may reduce cash flow, which reduces the chance of growth opportunities. During the past few years, there have been tremendous efforts on studying the effects of dividend on firms' performance.Australian firms pay dividends semi-annually with smaller "interim" payments and larger "final" payments (Balachandran et al., 2012) analyzed the interactions between the timing of dividends and their data content, controlling for share repurchase and tax impacts. They reported that market reaction was negatively associated with the reduction in imputation tax credit and reacted negatively to interim as compared with final dividend reductions. Chen et al. (2013) investigated the motivation behind the share repurchase decisions of initial public offering (IPO) firms by looking into the stock and operating

*Corresponding author. Tel: +98-912-3443139

E-mail addresses: f moslehi@iau-tnb.ac.ir (F. Moslehi) 
performance after the IPO date. They found that IPO companies that announce repurchases within three years of IPO dates exhibited poorer long-run abnormal operating performance than other IPO firms did. These IPO firms could also experience poorer stock return performance and they showed intensive insider selling transactions after the IPO date.

Gaspar et al. (2013) studied how shareholder investment horizons impacted payout policy choices. They inferred institutional shareholders' investment horizons using the churn rate of their overall stock portfolios before the payout decision and reported that the frequency and amount of repurchases could increase with ownership by short-term investors to the detriment of dividends. They explained that the market reacted less positively to repurchase announcements made by companies held by short-term institutions. Their results were consistent with a model in which undervalued business units signal their value through repurchases, but companies held by short-term investors make repurchased more often because those investors care about the short-term price reaction. They recommended that shorter shareholder investment horizons could be one contributing factor to the increasing popularity of buybacks.

Gaur et al. (2012) investigated the effect of acquisition announcements on the stock market returns of rivals of the acquiring firms and proposed a growth probability hypothesis. They examined the growth probability hypothesis with a longitudinal sample of Chinese domestic and cross-border acquisitions over the period 1993-2008. They reported robust support for this hypothesis as a tools to demonstrate market reactions to rivals of acquiring firms. Huang and Chan (2013) investigated the long-term stock returns following a substantial increase in debt. Mathur et al. (2013) studied how bond investors view corporate cash distributions through dividends and how that view influenced corporate expenditure of debt. Pienaar and Krige (2012) studied market reaction to open market share repurchases on the Johannesburg Stock Exchange over the period 2000-2007.

According to Rangvid et al. (2012) studied how professional predictors form equity market expectations based on a new micro-level dataset which includes rich cross-sectional information about individual characteristics. Sueyoshi and Goto (2013) discussed a use of data envelopment analysis-discriminant analysis to evaluate the corporate value of information technology companies and other manufacturing firms, known as Tobin's $\mathrm{q}$ as a ratio that serves as a measure of corporate value. Tekovic (2012) performed a performance measurement to determine a grade of intersystem interference effect from LTE signal to DVB-C2 system due to co-channelling. Won et al. (2012) implemented genetic algorithm based knowledge refinement model for dividend policy forecasting. Finally, Yu and Liang (2012) performed an empirical study for the performance of dividend policy based on financing constraints and agency cost trade-off.

\section{The proposed study}

In this research, dividend distribution policy is considered as a function of four independent variables namely Spread (SPREAD), bank size (Size), growth opportunity (AG) and cash flow (CASH) as follows,

$P-\operatorname{Div}_{i, t}=\beta_{0}+\beta_{1}$ Spread $_{i, t}+\beta_{2}$ Size $_{i, t}+\beta_{3} A G_{i . t}+\beta_{4}$ CASH $_{i, t}+\varepsilon_{i, t}$,

where $P$-Div $v_{i, t}$ is calculated as follows,

$P-\operatorname{Div}_{i, t}=\frac{\operatorname{Div}_{i, t}}{E P S_{i, t}}$,

where $\operatorname{Div}_{i, t}$ is the dividend of firm $i$ in period $t, E P S_{i, t}$ represents earning per share of firm $i$ in period t. SPREAD is a representative for the distance between bid price (BP) and ask price (AP) and is calculated as follows, 
Spread $_{i, t}=\frac{(B P-A P)}{(B P+A P) / 2} \times 100$.

For the implementation of Eq. (3), first we have extracted the best BP and AP, 21 days before and after earning estimate announcement. Growth opportunity is another variable of the proposed model of this paper. In fact, intangible assets are considered the most precious assets in many organizations, they can generate revenue and when a firm is bankrupted, they are easily removed from a business unit. A higher cash flow normally helps business take advantage of any investment opportunity and reduces the cost of borrowing. Small firms normally need to invest heavily on their infrastructures to maintain their steady growth. Finally, size of a firm is another important variable of this research considered for this study and we use natural logarithm of total assets to compute the size of the company. The main hypothesis of this survey is as follows,

$\mathrm{H}_{1}$ : There is a significant relationship between asymmetric information and dividend policies of private banks in the banking industry.

There are also two sub-hypotheses associated with the proposed study of this paper as follows,

1. There is a meaningful relationship between growth opportunity and dividend distribution policy among Iranian banking sector.

2. There is a meaningful relationship between cash flow retain and dividend distribution policy among Iranian banking sector.

3. There is a meaningful relationship between firm size and dividend distribution policy among Iranian banking sector.

The proposed study of this paper gathers the necessary information from all private banks whose shares are listed in Tehran Stock Exchange over the period 2005-2011. Table 1 shows some basic statistics on the data we have used.

\section{Table 1}

Some basic information on the input data

\begin{tabular}{lccccccc}
\hline & & & & & \multicolumn{2}{c}{ Deviation coefficient } \\
\cline { 5 - 8 } & Mean & Std. deviation & Variance & Skewness & Kurtosis & Skewness & Kurtosis \\
\hline Paid Dividend & 0.150 & 0.148 & 0.022 & 1.671 & 3.231 & 19.806 & 19.172 \\
Asymmetric information & 0.176 & 0.114 & 0.013 & 1.380 & 2.986 & 16.352 & 17.719 \\
Growth opportunity & 2.105 & 1.801 & 3.244 & 3.185 & 15.382 & 37.758 & 91.274 \\
Holding cash flow & 0.062 & 0.071 & 0.005 & 3.125 & 13.019 & 37.039 & 77.247 \\
Firm size & 5.785 & 0.623 & 0.388 & 0.997 & 1.099 & 11.817 & 6.521 \\
\hline
\end{tabular}

There are two independent variables including asymmetric information and growth opportunity and two control variables, which are firm size and holding cash flow. In order to verify the normality of the information, we use three tests of Kolmogorov-Smirnov, Shapiro Wilk and Jarkko Ruutu.

Table 2

The results of three different statistical tests

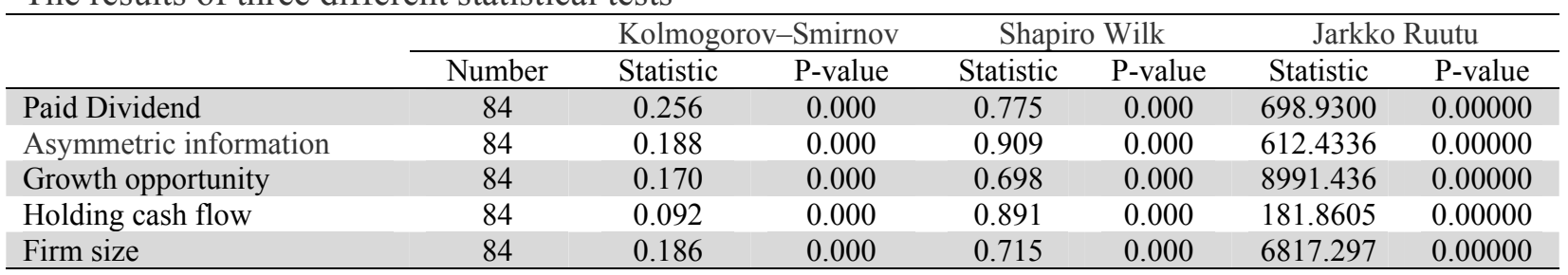

Table 2 demonstrates the results of our survey. The results of all three tests indicate that none of five variables is normally distributed. Next, we need to know whether we should use pooled or panel 
technique for regression analysis. We use Hausman and Chow tests to verify this kind of relationship and Table 3 shows details of our investigation.

\section{Table 3}

The results of Hausman and Chow tests

\begin{tabular}{lllllll}
\hline Test & & Chow & & \multicolumn{2}{c}{ Hausman test } \\
& F & Sig. & Result & Chi-Square & Sig. & Random effect \\
\hline Pooled & 1.218446 & 0.2975 & Equal intercept & & & \\
Pannel & 10.035152 & 0.0000 & Different intercept & 40.243901 & 0.0000 & Rejected \\
\hline
\end{tabular}

As we can observe from the results of Table 3, the implementation of random effect implies that there is no random effect. We also need to make sure that there is a linear relationship between the independent variables and dependent variable and since Fisher value, $\mathrm{F}=520$, is greater than critical value, $F_{c}=1.67$ when the level of significance is five percent, we can conclude that the relationship is indeed linear. The other concern is the correlation between residuals and the implementation of Durbin-Watson test yields 2.08, which is within the acceptable limit. The other issue is to look for the existence of linear relationship among independent variables. In fact, when there is a strong linear relationship, the final regression analysis will become unreliable.

\section{The results}

In this section, we present some of the results associated with the proposed model of this paper. We use ordinary least square technique to fit the proposed model presented in Eq. (1). Table 4 demonstrates the results of our investigations.

\section{Table 4}

The results correlations among independent variables

\begin{tabular}{lcccc}
\hline & Growth opportunity & Firm size & Asymmetry information & Retained Cash flow \\
\hline Growth opportunity & 1 & 0.021 & 0.401 & 0.109 \\
Firm size & 0.021 & 1 & 0.041 & 0.040 \\
Asymmetry information & 0.401 & 0.0417 & 1 & 0.222 \\
Retained Cash flow & 0.109 & 0.040 & 0.222 & 1 \\
\hline
\end{tabular}

As we can see from the results of Table 4, there is no strong correlation among independent variables and we can cautiously assume that the remaining weak correlation would no influence the results of our final regression model. Table 5 shows the results of our regression analysis. As we can observe from the results of Table 5, all $\mathrm{t}$-student values indicate that the coefficients of the regression analysis are statistically significant when the level of significance is five percent.

Table 5

The summary of regression analysis

\begin{tabular}{cccccc}
\hline Intercept & title & coefficient & Standard error & t-student & P-Value \\
\hline$\beta_{0}$ & $\mathrm{C}$ & -0.114109 & 0.045552 & -2.505004 & 0.0125 \\
$\beta_{1}$ & Spread & 0.371206 & 0.028352 & 13.09285 & 0.0000 \\
$\beta_{2}$ & $\mathrm{AG}$ & 0.003308 & 0.001684 & 1.963812 & 0.0500 \\
$\beta_{3}$ & $\mathrm{TA}$ & 0.019497 & 0.007975 & 2.444808 & 0.0147 \\
$\beta_{4}$ & $\mathrm{CASH}$ & 0.168821 & 0.030152 & 5.598984 & 0.0000 \\
$\beta_{5}$ & $\mathrm{Ar}(1)$ & 0.708243 & 0.023483 & 30.15955 & 0.0000 \\
\hline $\mathrm{R}^{2}=0.8577, \mathrm{AR}^{2}=0.8560, \mathrm{~F}=520.70, \mathrm{DW}=208, \mathrm{~S} E$
\end{tabular}

$\mathrm{R}^{2}=0.8577, \mathrm{AdR}^{2}=0.8560, \mathrm{~F}=520.70, \mathrm{D} . \mathrm{W}=2.08$, S.E.of regression $=0.069373$, Sum squared resid $=3.3255$

\subsection{The first hypothesis: Relationship between Growth opportunity and dividend policy}

As we can observe from the results of Table 5, there is a positive and meaningful relationship between growth opportunity and dividend pay (0.003308) and we can confirm the first hypothesis of this survey. 


\subsection{The second hypothesis: Relationship between bank size and dividend policy}

As we can observe from the results of Table 5, there is a positive and meaningful relationship between bank size and dividend pay (0.019497) and we can confirm the second hypothesis of this survey.

\subsection{The third hypothesis: Relationship between retained cash flow and dividend policy}

As we can observe from the results of Table 5, there is a positive and meaningful relationship between bank size and dividend pay (0.168821) and we can confirm the third hypothesis of this survey.

In summary, all hypotheses of this survey have been confirmed and we can conclude that there was a positive and meaningful relationship between growth opportunity and dividend pay (0.003308). In addition, there was a positive and meaningful relationship between bank size and dividend pay (0.019497) and finally, there was a positive and meaningful relationship between bank size and dividend pay (0.168821).

\section{Conclusion}

In this paper, we have presented a survey to investigate the impact of asymmetric information and growth opportunities on dividend policies among some private banks in Iran. The proposed study of this paper gathered the necessary information from all private banks whose shares were listed in Tehran Stock Exchange over the period 2005-2011. The study used regression analysis to study the impacts of different factors where dividend distribution policy was considered as a function of four independent variables namely spread, bank size, growth opportunity and cash flow. The results of the survey indicate that there was a positive and meaningful relationship between growth opportunity and dividend pay (0.003308). In addition, there was a positive and meaningful relationship between bank size and dividend pay (0.019497) and finally, there was a positive and meaningful relationship between bank size and dividend pay $(0.168821)$.

\section{References}

Balachandran, B., Krishnamurti, C., Theobald, M., \& Vidanapathirana, B. (2012). Dividend reductions, the timing of dividend payments and information content. Journal of Corporate Finance, 18(5), 1232-1247.

Chen, S., Ho, K. W., Huang, C., \& Wang, Y. (2013). Buyback behavior of initial public offering firms. Journal of Banking and Finance, 37(1), 32-42.

Gaspar, J., Massa, M., Matos, P., Patgiri, R., \& Rehman, Z. (2013). Payout policy choices and shareholder investment horizons. Review of Finance, 17(1), 261-320.

Gaur, A. S., Malhotra, S., \& Zhu, P. (2013). Acquisition announcements and stock market valuations of acquiring firms' rivals: A test of the growth probability hypothesis in china. Strategic Management Journal, 34(2), 215-232.

Huang, H., \& Chan, M. (2013). Long-term stock returns after a substantial increase in the debt ratio. Applied Financial Economics, 23(6), 449-460.

Mathur, I., Singh, M., Nejadmalayeri, A., \& Jiraporn, P. (2013). How do bond investors perceive dividend payouts? Research in International Business and Finance, 27(1), 92-105.

Pienaar, H. P., \& Krige, J. D. (2012). Market reaction to open market share repurchases on the johannesburg stock exchange over the period 2000 to 2007. Journal for Studies in Economics and Econometrics, 36(3), 101-122.

Rangvid, J., Schmeling, M., \& Schrimpf, A. (2013). What do professional forecasters' stock market expectations tell us about herding, information extraction and beauty contests? Journal of Empirical Finance, 20(1), 109-129. 
Sueyoshi, T., \& Goto, M. (2013). A use of DEA-DA to measure importance of R\&D expenditure in japanese information technology industry. Decision Support Systems, 54(2), 941-952.

Tekovic, A. (2012). LTE in digital dividend: Deployment challenges - DVB-C2 case. Paper presented at the Proceedings Elmar - International Symposium Electronics in Marine, 251-254.

Tekovic, A., Šimac, G., \& Šakić, K. (2012). LTE downlink system performance measurement with intersystem interference caused by DVB-T signal. Paper presented at the Proceedings Elmar International Symposium Electronics in Marine, 255-258.

Won, C., Kim, J., \& Bae, J. K. (2012). Using genetic algorithm based knowledge refinement model for dividend policy forecasting. Expert Systems with Applications, 39(18), 13472-13479.

Yu, L., \& Liang, T. (2012). The performance of dividend policy - based on financing constraints and agency cost trade-off. Paper presented at the Proceeding of 2012 International Conference on Information Management, Innovation Management and Industrial Engineering, ICIII 2012, $1,455-459$. 